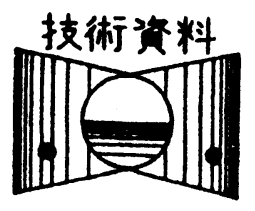

\title{
ディーゼル機関の軸材及び 軸受材の摩耗性評価*
}

\section{1. まえがき}

ディーゼル機関のすべり軸受は, 高速回転化・燃 焼圧力上昇に上る低燃費化 - 軽量化 - 低質油使用等 により, 年々, 使用条件が過酷さを加え, 耐久性・ 信頼性について注目されている. その中には, 軸受 及び軸の摩耗に起因するとみられる損傷事例があり その改善が望まれている. 摩耗原因としては軸受使 用条件の過酷化・低質油使用による潤滑油中の不溶 解分増加・潤滑油中の異物混入などが上げられる ${ }^{1)}$.

今まで, 軸受材の耐摩耗性・耐久性を評価した報 告はみられるが, 軸受材特性之関連する軸材の耐摩 耗性・耐久性について評価した報告は僅かであ る ${ }^{2,3)}$.

本報告では，軸材及び軸受材の表面条件や材質を 変えて, 異物を混入した潤滑油により軸材及び軸受 材の摩耗試験を行い, 両材の相互摩耗に及ぼす影響 について評価試験を実施したので，その結果につい て報告する. また，軸受に入り込んだ異物は軸受表 面に埋収されるが, その埋収状況が軸の摩耗に影響 すると考えられる. 特に, オーバレイ層が表面にあ る場合, 異物はオーバレイ層内に深く埋め込まれ, 表面への露出が減少し軸の摩耗を軽減する方向に働 くと予想される.軸受表面の影響を調べるため, オー

\footnotetext{
*原稿受付 平成 6 年 3 月 17 日

平成 5 年春季学術講演 (平成 5 年 5 月 27 日)

平成 5 年秋季学術講演（平成 5 年10月14日）

**正会員 (株新潟鉄工所原動機事業部技術部 （東京都大田区蒲田本町 1-3-20) ***正会員 陎新潟鉄工所原動機事業部六日町工場設計課 （新潟県南魚沼郡六日町大字川窪字窪1111） ****大同メタル工業(株技術研究所トライボセンター （愛知県犬山市大字前原字天道新田） *****大同メタル工業(侏技術研究所トライボセンター
} （愛知県犬山市大字前原字天道新田）

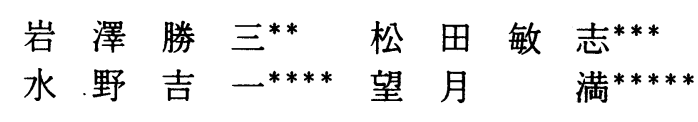

バレイの表面積を変えて摩耗試験を行った．また， 油膜厚さを変えて軸及び軸受の摩耗量への影響を調 べた.これらの結果について報告する.

\section{2. 実験}

2. 1 試験機本実験に使用した装置は, 軸 受摩耗試験機を改造したもので，その機構概略を図 1 に示す. 本試験装置は, 十分剛性を持つ片持支持 軸受として，試験軸のたわみによる軸受の片当たり が発生しないように設計している.

2.2 試験軸受及び試験軸試験軸受及び 試験軸材の化学組成・機械的性質等について表 1 に 示す.

軸受は, $\mathrm{PbSnCu}$ の 3 元のオーバレイメッキ層(厚 さ20 $\mu \mathrm{m}$ ，表面積率100\%）をもつ軸受を標準的に 使用したが，一部地金の合金層を露出させて軸受の オーバレイの表面積率を変えた軸受を, 表面の影響 を評価するために使用した．また，軸材は，クラン ク軸に採用されているCrMo鋼の調質軸材であり, 調質硬さを変えたもの, 高周波焼入れしたもので硬 さの影響を, また, 軸の表面粗さを 3 種類の仕上加

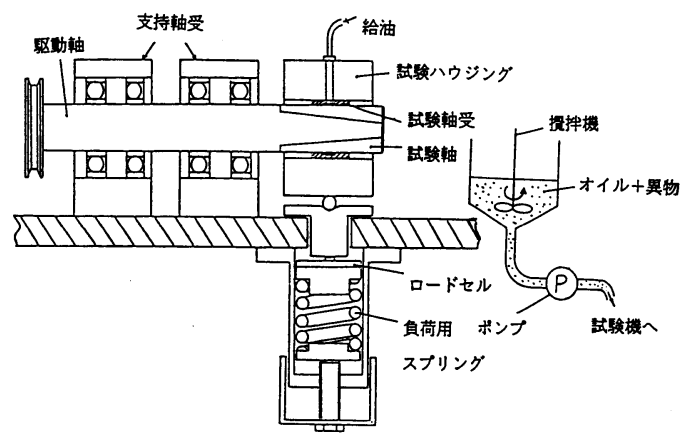

図 1 軸 $/$ 軸受材摩耗基礎試験機機構図 
表 1 供試材の成分及び物性

\begin{tabular}{|c|c|c|c|c|}
\hline 供試材 & \multirow{2}{*}{$\begin{array}{cc}\text { 項 } \text { 目 } \\
\text { 分 } \\
\end{array}$} & \multicolumn{2}{|c|}{ 内 } & 容 \\
\hline \multirow[t]{5}{*}{ 軸 } & & (A) & (B) & $(C)$ \\
\hline & 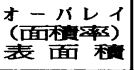 & $\begin{array}{c}\mathrm{Pb}-\mathrm{Sn}-\mathrm{Cu} \\
(100 \%)\end{array}$ & $\begin{array}{c}\mathrm{Pb}-\mathrm{Sn}-\mathrm{Cu} \\
(70 \%)\end{array}$ & $(0 \%)$ \\
\hline & 中既同 & $\mathrm{Ni}$ & $\mathrm{Ni}$ & $\longrightarrow$ \\
\hline & 合 金 & $\begin{array}{l}\mathrm{Cu}-\mathrm{Pb} \\
\text { 合金 }\end{array}$ & $\begin{array}{l}\text { A }_{\text {e }}-Z_{n-} \\
\text { S }_{\text {i }} \text { 合金 }\end{array}$ & $A \ell-S n$ \\
\hline & 重 & Steel & Steel & Stee 1 \\
\hline \multirow[t]{4}{*}{ 軸 } & 材 & \multicolumn{3}{|c|}{ SCM440 } \\
\hline & 表面処理 & \multicolumn{3}{|c|}{ 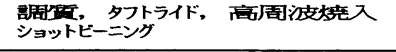 } \\
\hline & 粗 & \multicolumn{3}{|c|}{$P \max 1 \mathrm{~S}, 2 \mathrm{~S}, 3 \mathrm{~S}$} \\
\hline & 硬 & \multicolumn{3}{|c|}{ HS30 $\sim 80$} \\
\hline
\end{tabular}

\section{表 2 供試験軸の表面処理仕様}

\begin{tabular}{|c|c|c|}
\hline $\begin{array}{l}\text { タフトライド処理 } \\
\text { ('T処理) }\end{array}$ & \multicolumn{2}{|c|}{$\begin{array}{c}\text { ショットビーニング処理 } \\
\text { (SP処理) }\end{array}$} \\
\hline $\begin{array}{l}\text { (三材:諳周 } 22 \\
(\mathrm{HS} 40) \text { (d) }\end{array}$ & $\begin{array}{l}\text { (青材: : 調 } 2 \\
(\mathrm{HS40}) \text { (C) }\end{array}$ & $\begin{array}{l}\text { (走材:高)固波炾入 } \\
\begin{array}{ll}(\mathrm{HS} 72)) & \text { (f) }\end{array}\end{array}$ \\
\hline $\begin{array}{l}\text { カス軟登化 } \\
\text { 処理 } \\
570^{\circ} \mathrm{C} \times 4 \mathrm{~h} \\
\text { 油 冷 }\end{array}$ & 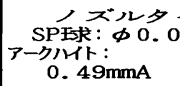 & $\begin{array}{c}\text { イプSP処理 } \\
\text { 6mm/HRC53/鋼救 } \\
\text { アークハHト : } \\
0.55 \mathrm{mmA}\end{array}$ \\
\hline
\end{tabular}

表 3 試験項目

\begin{tabular}{|c|c|c|}
\hline 項 目 & 軸受材公 & 軸表面処理（硬さ） \\
\hline 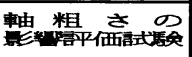 & (A) & (b) 調的 2 (HS40) \\
\hline \multirow{3}{*}{ 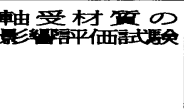 } & (A) & \multirow{3}{*}{$\begin{array}{l}\text { 調 } 2 \text { (HS40) } \\
\text { 高周波智入 } \\
\text { (HS72) }\end{array}$} \\
\hline & (B) & \\
\hline & (C) & \\
\hline \multirow{6}{*}{ 輤表面面処理の } & \multirow{6}{*}{ (A) } & (a) 調 1 (HS30) \\
\hline & & (b) 調姃2 (HS40) \\
\hline & & 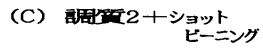 \\
\hline & & (d) タフトライド \\
\hline & & (e) 高周波势入 \\
\hline & & $\begin{array}{l}\text { (f) 周波焼入十 } \\
\text { ショッドーシグ }\end{array}$ \\
\hline
\end{tabular}

エしたもので, 表面粗さの影響について評価するこ ととした．硬さ以外の影響要因があるかを調べるた め, 更にクランク軸適用害績のある代表的な表面処 理であるタフトライド処理（以下T処理という。）, また, 最近注目されているショットピーニング処理 （以下SP処理という.）の表面処理を施行した場 合について，比較試験を実施した， T処理及びSP 処理の主要仕様を表 2 に, 樑さ方向の硬さ分布の測 定結果を図 2 に示す. 軸の高周波焼入れ表面にSP 処理を施行したものは表面層に微少の硬さ上昇が認 められる.

2. 3 实験方法 本実験では, 潤滑油として

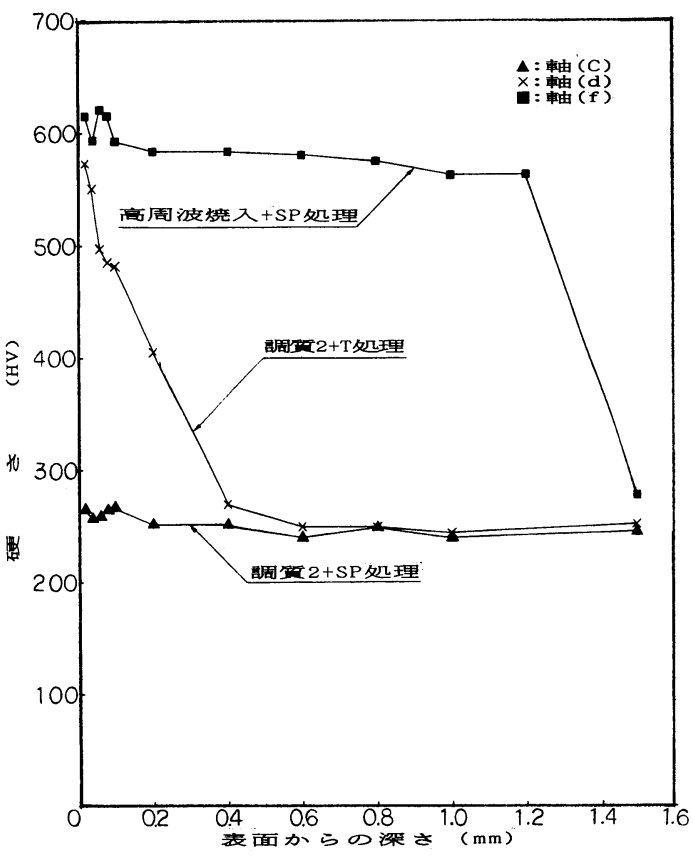

図 2 供試材の研摩後の硬さ分布

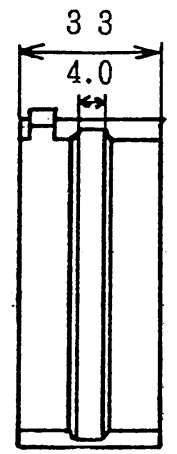

ロ ア -

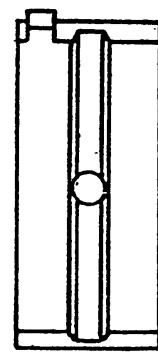

アッパー

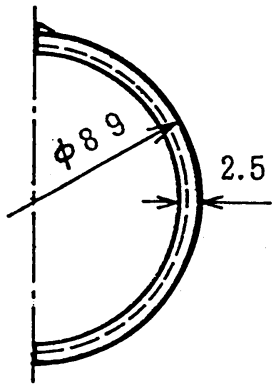

図 3 軸受寸法
灯油を使用し, 潤滑油中の不溶解分に代わり，砂系 異物を混入して摩耗試験を実施した。潤滑油として, 灯油を採用した理由は, 室温条件下において, ディー ゼル機関の軸受油膜厚さに近い条件が得られるため である．また，試験軸受の寸法形状を図 3 に示す. 本図に示すように $4 \mathrm{~mm}$ 幅の全周油溝を付けて, 負荷 を大きくすることとし, 軸の焼損が発生せず, かつ, 計測される摩耗量が比較的短時間で評価するに十分 な量となるよう条件選定した。

本実験は, 軸受材の表面条件及び軸材の表面粗さ 之表面処理を变えた摩耗評価試験であり，これらの 
表 4 試験条件

\begin{tabular}{|c|c|}
\hline 項 回 & 内 \\
\hline 㟟物 (一) & 砂乐 $\mathrm{SiO}_{2}(30 \mathrm{mg} / \ell)$ \\
\hline 回 車云 数 & $3600 \mathrm{rpm}$ \\
\hline 面 压 & 1. $5 \mathrm{MPa}$ \\
\hline 潤 泪 油 & 白灯油 \\
\hline 入口湦度 & 实温 $\left(20^{\circ} \mathrm{C} \sim 25^{\circ} \mathrm{C}\right)$ \\
\hline 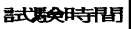 & 12时简 \\
\hline
\end{tabular}

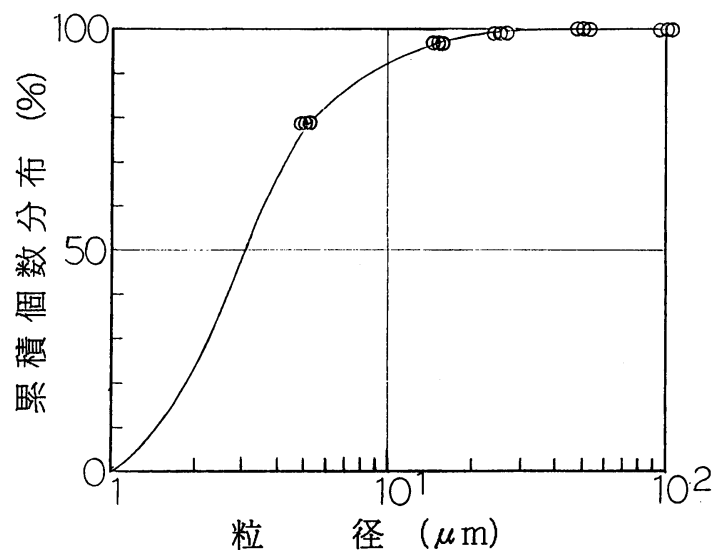

图 4 油中異物の糸栍粒径分布

試験項目を表 3 に示す．また，最終選定した試験条 件を表 4 に示す.

油中に混入した異物ダストは白砂 $\left(\mathrm{SiO}_{2}\right)$ であ り異物の粒径分布計測結果を図 4 に示す．粒径は殆 ど25 $\mu \mathrm{m}$ 以下としてディーゼル機関に採用されてい る潤滑油フィル夕の滤過実績に近い条件とした.

軸摩耗量の測定は, 最大摩耗部を精密表面粗さ計 により計測し, 初期基準面からの摩耗量を面積とし て計測して平均朝摩耗量を算出した。軸摩耗量の測 定方法を図 5 に示す．また，軸受摩耗量の測定は試 験前後において重量計測を行い軸受体積減を算出し て軸受摩耗量とした。

2. 4 潤滑油内粒子锶案軸之軸受間の摩 耗状況を調べるため, 潤滑油内の摩耗粒子をフェロ グラフィ法によって調查した. 図 6 に分析フェログ ラフィ法による, 摩耗試験時間内 $(12 \mathrm{~h})$ の摩耗粒 子量の変化を示す．本図から摩耗粒子量はほぼ直線 的に増加していることがわかる，従って，摩耗試験 時間の範囲内では，比較的定常な摩耗の状態にある 之考えられる. また，摩耗粒子の観察結果，大部分 は鉄系の正常なラビング粒子であったが，まれに切 り粉状のカッテングがみられた，以上により，異物
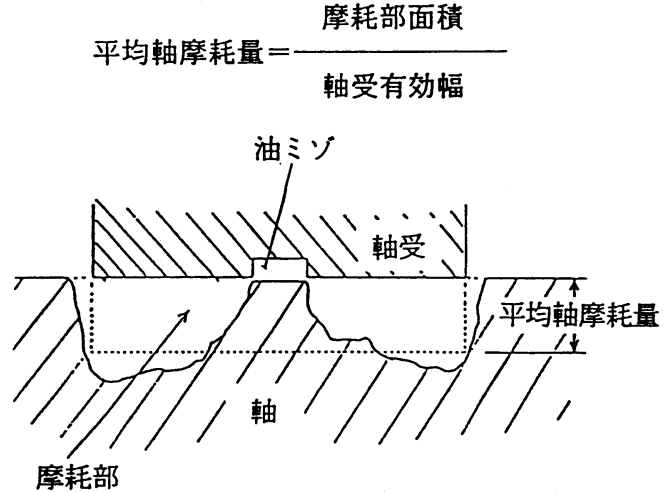

図 5 軸摩耗量の測定方法

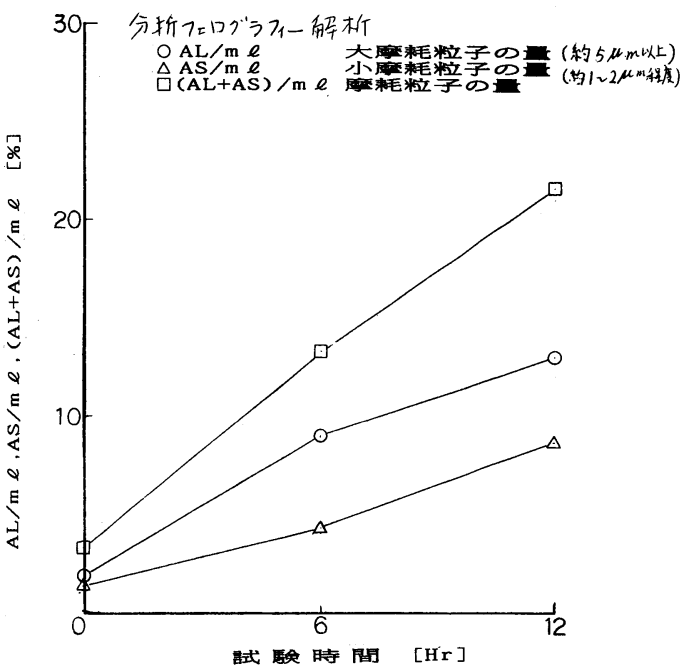

図 6 潤滑油内粒子観察（分析フェログラ フィ)

混入試験の摩耗は，ラビング粒子となる剝離層が定 常的に生成，はく落をくりかえす摩耗状態であると 考えられる.

2. 5 軸及び軸受内埋収物観察軸受への 異物の埋収状態が, 軸の摩耗に影響すると考えられ るため，軸及び軸受の摺動面についてEPMA 観察 により調查した，図 7 は，軸及び軸受内埋収物の EPMA観察結果の代表例を示す。軸受表面には, 投入した白砂 $\left(\mathrm{SiO}_{2}\right)$ 成分である $\mathrm{Si}$ 及びO と軸の 摩耗粉であるFeが認められ, その埋収位置は主と して荷重部と荷重部上流に分布している. 一方, 軸 表面においてもSi及びOや，軸受の成分である $\mathrm{Pb}$, Snが微量検出され, 軸の摺動面にも付着又は埋収 


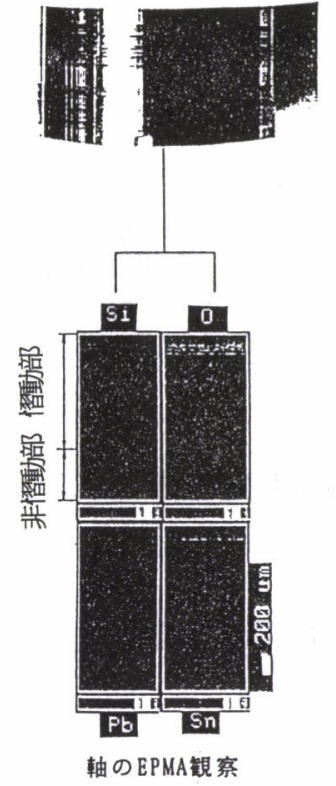

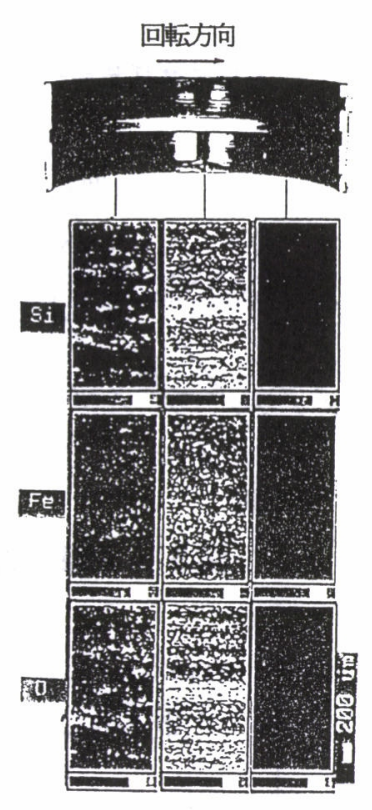

軸受のEPMA钼察

軸：調質2 (Hs40)，軸受：表面層付Cu-Pb合金

\section{図 7 軸及び軸受埋収物のEPMA観察}

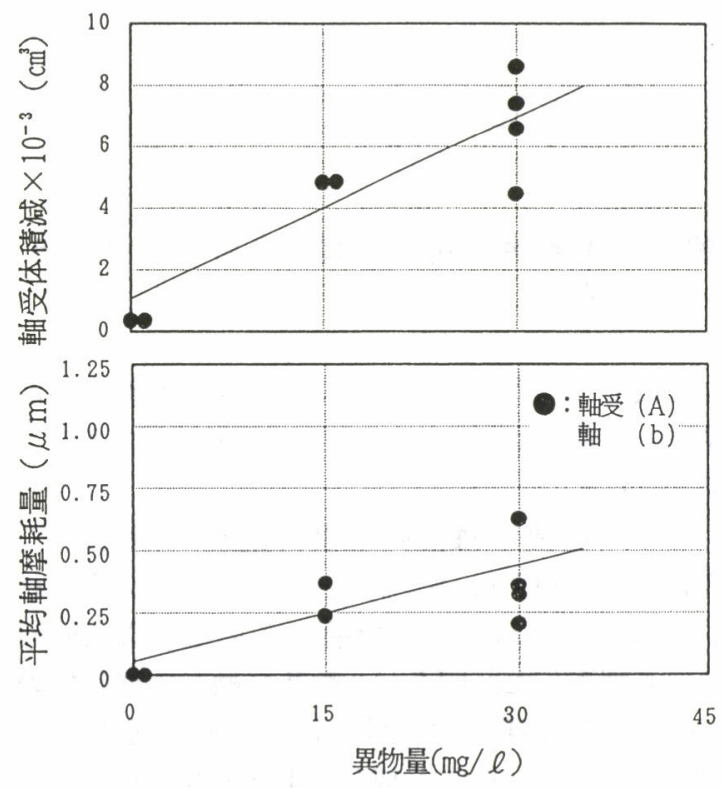

図 8 油中異物量の影響

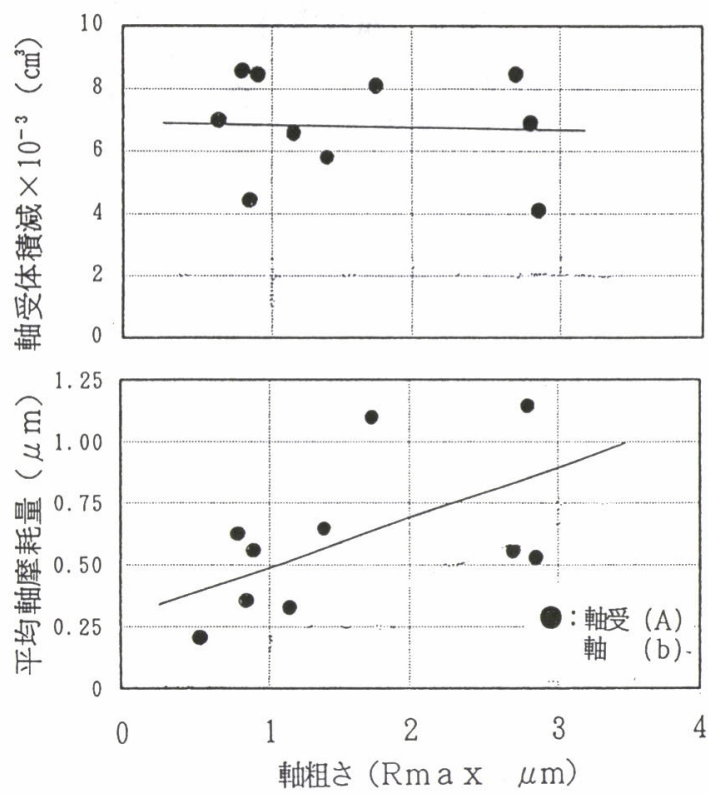

図 9 軸表面粗さの影響

\section{3. 実験結果と考察}

3. 1 油中異物有無による摩耗軸受材及 び調質軸材（Hs40，Rmax1.0S以下）を一定条件 として, 灯油中異物の有無による比較試験を実施し た. その結果を図 8 に示す．油中の異物が全く無く， 新油状態であれば, 軸材の摩耗は殆ど認められず, また, 軸受材の摩耗はごく微少発生しているとみら れる状況であった．実際のディーゼル機関において, 潤滑油フィルタの濾過能力を向上させて異物混入量 を極力減少させれば, 重要部品であるクランク軸の 摩耗量を減少させることができると推察される.

\section{2 軸材の表面粗さの影響軸を調質硬} さHs40の一定条件として, 表面粗さは, クランク 軸現状仕上実績となっている $\mathrm{Rmax} 0.5 \sim \mathrm{R}$ max $3.0 \mathrm{~S}$ 範囲内で比較試験を実施した。 その結果を図 9 に示す. 軸材表面粗さが粗くなると軸材の摩耗量 は増加する傾向にあることが認められた。一方, 軸 受材の摩耗量については明確な相関性が認められな かった.

本結果から軸材表面粗さを向上することは, クラ ンク軸の摩耗量を減少させることができる要素と考 えられる. 

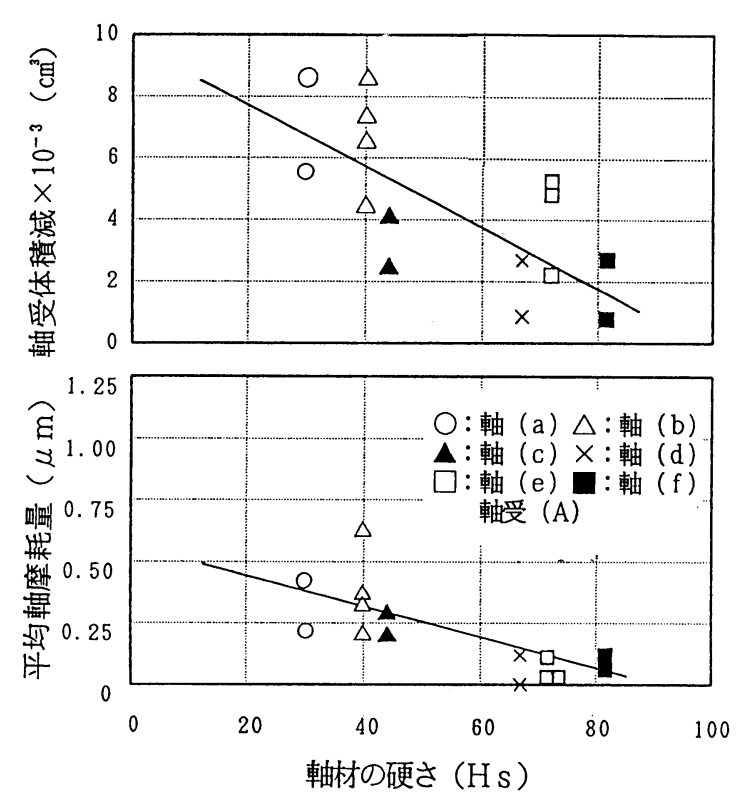

図10 軸表面処理の影瞕
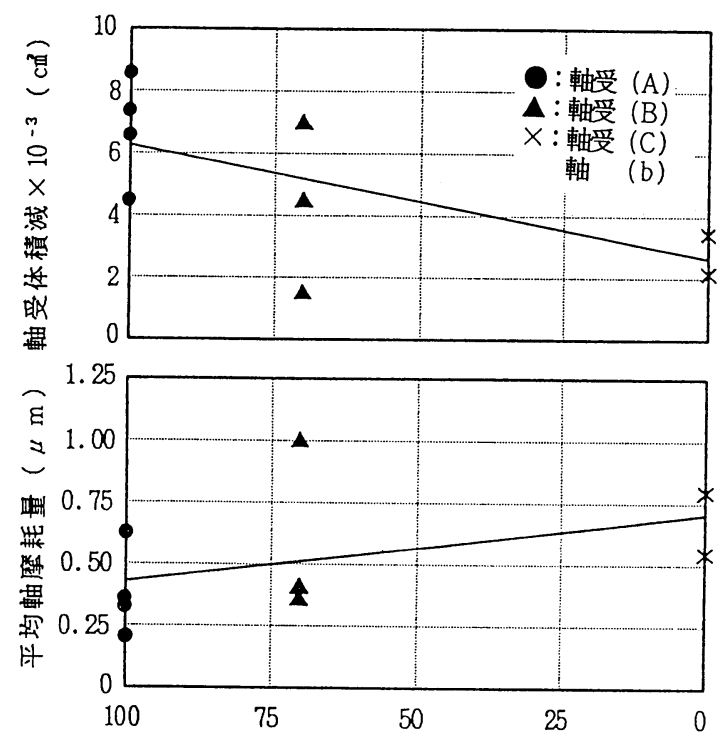

オーバレイ表面層の面積率（\%)

\section{因11軸受材斯の影管}

\section{3 軸表面処理の影䇾軸材硬さは,, ク} ランク軸材の調質のままの硬さから高周波焼入をし た場合の硬さを想定して，Hs30〜Hs72の範囲内で 比較試験を実施した. 更にT処理あるいはSP処理 の表面処理を加えて, 軸表面処理の影響について の試験も実施した。ここで，軸材の表面仕上は
$\mathrm{Rmax} 1.0 \mathrm{~S}$ 以下の一定条件としている.これらの 試験結果を図10に示す．軸材硬さを硬くすると軸材 及び軸受材とも摩耗量は減少して, 軸材の最も硬い Hs72においては軸材の摩耗量は非常に少なく, 硬 さの影響が大きいことを表している.

軸材硬さが硬い場合（Hs72），軸及び軸受材の 摩耗量が少ないという結果から, 軸受材の摩耗は軸 側の表面状態に大きく影響を受けていると考えられ る. 前述の表面粗さの試験を考察すると, 使用した 軸の硬さはHs40であり, 異物によって摩耗し易く, 表面の凹凸も大きいと考えられる. Rmax1.0S以 下の軸であっても, 異物による摩耗で, 時間之共に 表面の凹凸は大きくなり, 表面粗さとは無関係に朝 受側の摩耗を促進したと考えられる. また， T処理 あるいはSP処理の表面処理により軸材硬さを硬く すると軸材及び軸受材とも摩耗量は減少して, 両材 の摩耗量はほぼ硬さに依存していることが確認され た. 従って, 本試験のような異物 $\left(\mathrm{SiO}_{2}\right)$ に対し て, T処理, SP処理, 高周波焼入れ等の処理方法 の影響は小さく, 硬さの要素が支配的であることが わかった。

\section{4 軸受材䭭の影敏 軸を調質硬さHs 40 ,} 表面粗さ $\mathrm{R} \max 1.0 \mathrm{~S}$ の一定条件として, 軸受の オーバレイの表面積率を100\%，70\%，0\%之変え た試験結果を図11に示す. 軸受のオーバレイの表面 積率が大きくなるに従って, 軸材の摩耗量は減少し, 軸受材の摩耗量は増加する結果となった．本結果よ り次のように考えられる．オーバレイ層に取り込ま れた異物は深く埋収し，摺動面への露出量を少なく， 軸の摩耗を軽減する方向に㗢く，これに対して，合 金層が露出したものは，合金層が硬いため，異物の 埋収は不完全で, 異物が摺動面に露出し軸の摩耗を 増加させる。

\section{5 油膜厚さの影讋軸材及び軸受材の} 摩耗量を減少させる方法として, 油膜厚さを厚くす ることが有効な手段と予想される，そこで，潤滑油 の油種を変えて計算上の最小油膜厚さ ( $\mathrm{Hmin})$ を $2.1 \mu \mathrm{m}$ から $8.5 \mu \mathrm{m}$ 範囲内で比較試験を実施した.

軸材はHs40調質材を使用し，表面粗さはRmax 1.0 $\mathrm{S}$ に仕上げた。軸受は, $\mathrm{PbSnCu}$ の 3 元のオーバレ イメッキ付軸受とした. 本試験結果を図12に示す. Hminが厚くなるに従って軸及び軸受の摩耗量とも 予想通り減少することが確認された。しかし，8.5 $\mu \mathrm{m}$ の油膜厚さにおいてもかなりの摩耗がみられ, 

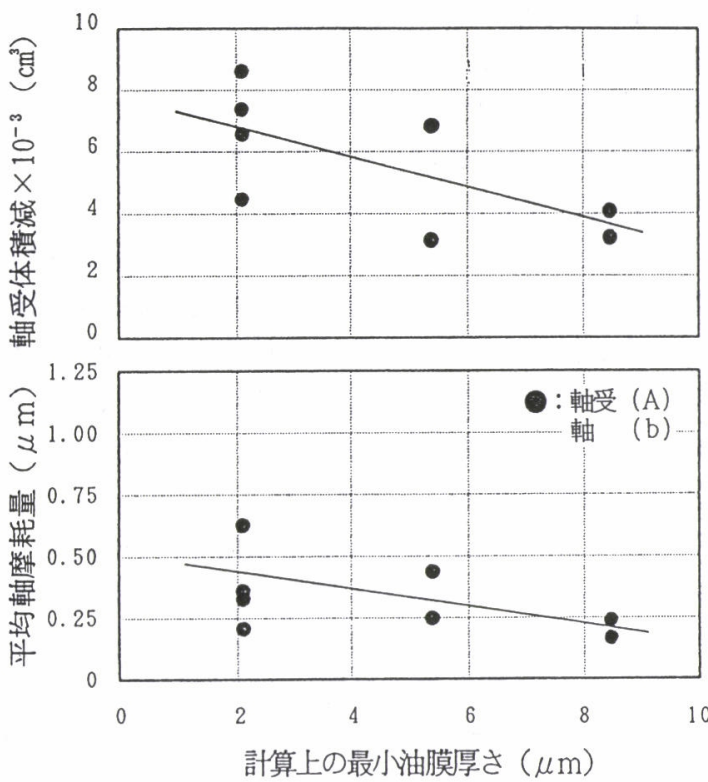

図12 最小油膜厚さの影響

大きな異物を含む潤滑油に対しては，異物をフィル 夕で除去することが有効と考えられる．また，軸及 び軸受の寿命延長のために, 極力油膜厚さを厚くす ること，すなわち潤滑油の粘度を上昇させることは 有効であると考えられる。

\section{4. まとめ}

本実験結果から注目されることを下記する.

（1）油中の異物が全く無く，新油状態であれば, 軸材の摩耗は全く認められず, 軸受材の摩耗は ごく微少発生する状態である.

（2）軸材表面粗さが粗くなると, 軸材の摩耗量は 増加するが, 軸受材の摩耗量については, 明確 な相関性が認められない。

（3）軸材硬さを硬くすると，軸材及び軸受材とも 摩耗量は減少する，また，表面処理方法による 影響は少なく，硬さに依存している.

（4）軸受のオーバレイ表面積率が大きくなるに 従って, 軸材の摩耗量は減少し軸受材の摩耗量 は増加する。

（5）軸受の油膜厚さが厚くなるに従って，軸材及 び軸受材の摩耗量を減少させる.
文献

1) 森早苗, 潤滑, 第17巻第11号 (1972)， 37

2 ）朝鍋 - 佐木 - 他, 三菱重工技報, 24-2（1987）, 109

3 ) 萩野, 他, 舶機学学術講演前刷集, (昭和59-秋), 113

4 ) 岩澤 - 水野 - 他, 舶機学学術講演前刷集（平成 $5-$ 春) , 211

5 ) 岩澤 - 水野 - 他, 舶機学学術講演前刷集 (平成 5 秋)， 165

\section{[質 疑 応 答]}

質問者 三井造船(侏ディーゼル工場研究部 田中正 紀

〔質問】軸側の粗さを変えているが, 加工の具体 的な方法を教えてほしい.

(Grinding $\rightarrow$ Polishing ?)

〔回答〕軸側の粗さR max1.0S〜3.0S 仕上は, Grinding仕上げです.
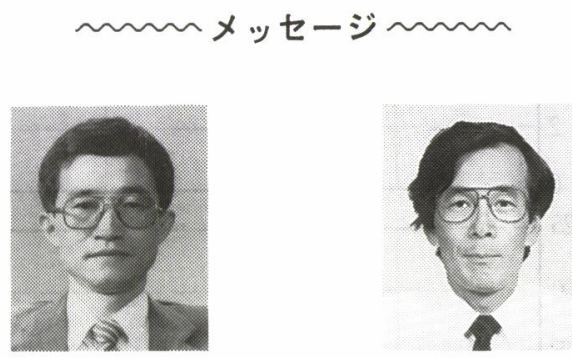

岩 澤 勝 三

松田敏 志
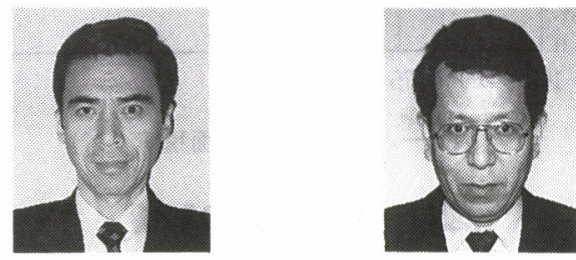

水 野 吉一

望月満

ディーゼル機関の軸受を取りまく環境は，厳しくなる一方 で, 信頼性向上や長寿命が要求され, 軸受性能は多方面から 検討する必要が生じている. 軸受の摩耗といえば, 軸受本体 について議論されることが多く, 軸については定性的に語ら 
れることが多かった．エンジンの高出力・高回転化により，う一般的に取扱いにくいテーマに挑戦した結果の一例であり， クランク軸の摩耗という問題も無視できなくなってきたため, 複雑な摩耗の問題の一つの切り口かと思い, 軸受をめぐる䋙 軸の摩耗にスポットをあてて取組んでみた，今回，異物といしい状況に，ひとつでも役に立てばよいと考えている. 